\title{
Naip Ovası ve Yakın Çevresindeki Taş Ocaklarında Zamansal ve Mekânsal Değişimlerin Çevresel Etkileri (Tekirdağ)
}

\author{
Emre ÖZŞAHİN ${ }^{*}$, Hüseyin SARI ${ }^{2}$, İlker EROĞLU ${ }^{1}$ \\ ${ }^{1}$ Namık Kemal Üniversitesi Fen-Edebiy at Fakültesi Coğrafya Bölümü, Tekirdağ, Türkiye \\ ${ }^{2}$ Namık Kemal Üniversitesi Ziraat Fakültesi Toprak Bilimi ve Bitki Besleme Bölümü, Tekirdağ, Türkiye \\ *e-posta: eozsahin@nku.edu.tr; Tel: +90 (282) 250 2696; Fax: +90 (282) 2509925
}

Öz: Son yıllarda kontrolsüz bir biçimde artan şehirleşmenin etkisiyle yapı malzemelerine olan ihtiyacın karşılanması, Türkiye şartlarında genellikle tuğla ve kiremit fabrikalarında imal edilen ürünlerle sağlanmaktadır. $\mathrm{Bu}$ ürünlerin imalatında kullanılan malzemeler ise daha çok açık işletme şeklinde faaliyet gösteren taş ocaklarından elde edilmektedir. Ancak kontrolsüz ve yoğun bir şekilde kullanılan taş ocakları zamanla çeşitli çevre sorunlarına yol açmaktadır. Bu çalışmada Türkiye'nin tuğla ve kiremit sektöründeki ana üretim bölgelerinin başında gelen Tekirdağ ilindeki en önemli üretim alanı olan Naip Ovası ve yakın çevresinde, tuğla ve kiremit sektörüne ait hammaddenin temin edildiği taş ocaklarında zamansal ve mekânsal değişimlerin çevresel etkilerinin açıklanması amaçlanmıştır. Çalışma kapsamında sahadaki taş ocaklarının yakın geçmişteki (2012) ve günümüzdeki (2017) durumu, su ve toprak örneklerinin analiz sonuçlarına dayalı yersel veriler ile CBS ve UA teknikleriyle desteklenen görüntü analizleri çerçevesinde çözümlenmeye çalışılmıştır. Böylece hem Trakya Yarımadası'nın hem de Tekirdağ ilinin en önemli yer şekillerinden biri olan Naip Ovası'nın açık işletme şeklinde uygulanan madencilik faaliyetlerinden ne derecede ve hangi yönde etkilendiği ortaya çıkarılmıştır. Çalışma sonuçları, Naip Ovası ve yakın çevresindeki taş ocaklarında önemli oranda zamansal ve mekânsal değişimlerin yaşandığını göstermiştir. Kontrolsüz bir biçimde gerçekleşen bu değişimler, ekolojik, ekonomik ve estetik yönlerden coğrafyayı etkileyen çevresel etkilere yol açmışır. Ortaya çıkan bu sorunların çözümü için öncelikle sürdürülebilir bir planlamanın yapılması gerekmektedir. Aksi takdirde yakın gelecekte Naip Ovası çevresindeki hassas ekosistemlerde geri dönüşü olmayan kayıplar şeklinde muhtemel sorunların ortaya çıkması kaçınılmaz olacaktır.

Anahtar kelimeler: Naip Ovası, Taş ocağı, Tekirdağ, Zamansal ve mekânsal değişim

\section{Environmental Effects of Spatiote mporal Change in Quarries in Naip Plain and its surroundings (Tekirdag)}

\begin{abstract}
The need for building materials in Turkey, increasing in recent years as a result of uncontrolled growth of urbanization, is mostly met with products made in brick and tile factories. The materials used for making these products are obtained from quarries, which mostly operate as open pits. However, uncontrolled and intensive use of quarries leads to various environmental problems in the course of time. This study aims to explain the environmental effects of temporal and spatial changes in the quarries from which raw materials for brick and tile industries are extracted in the Naip Plain and its vicinity, standing as the most important production zone in the Tekirdag province, which is one of the primary brick and tile production areas in Turkey. Within the scope of the study, the states of the quarries in the area in the recent past (2012) and at the present time (2017) were tried to be analyzed through ground data based on the analysis results of water and soil samples and the image analyses supported by GIS and RS techniques. In this way, the degree and the way the Naip Plain, which is one of the most important geographical formations of both the Thracian Peninsula and the Tekirdag province, is affected by mining activities performed as an open pit were revealed. The findings of the study indicate that significant temporal and spatial changes took place in the quarries located in the Naip Plain and in its close vicinity. These uncontrolled changes brought about environmental effects influencing the region in ecologic, economic, and aesthetic terms. The solution of these problems requires a sustainable plan in the first place. Otherwise, irreversible losses may be experienced by the sensitive ecosystems around the Naip Plain in the near future.
\end{abstract}

Keywords: Naip Plain, Quarry,, Tekirdag, Spatiotemporal Change 


\section{Giriş}

Son yıllarda Türkiye'de şehirleşmenin belirgin olduğu yerleşim merkezlerine yakın alanlarda artan ihtiyacı karşılamak üzere tuğla ve kiremit sektörüne ait fabrikalar çok hızlı bir şekilde yaygınlaşmıştır (Şahin 2001). Bu fabrikalarda kullanılan hammaddeler, daha çok aynı sahadan veya yakın çevredeki maden ocaklarından temin edilmektedir. Üretim kayıplarının çok düşük olmasının yanında (Goergen ve ark. 1981) üretim hızının yüksek olması ve çalşanlar için daha uygun koşullar sunmasından dolayı hem Dünya'da hem de Türkiye'de bu tür faaliyetlerin büyükçoğunluğu açık işletme şeklinde yürütülmektedir (Dumlu 2014).

Günümüzde insan nüfusunun hızla artmasına paralel olarak gelişen inşaat sektörü madencilik faaliyetlerinin daha da önem kazanmasına sebep olmuştur (Özcan 2009). Maden ocaklarının daha yoğun bir şekilde kullanımına yol açan bu durum, çeşitli çevre sorunlarını da gündeme taşımıştır (Özcan ve Akpınar 2009; Borand 2012). Bilhassa açık işletme şeklinde yapılan madencilik faaliyetleri, mevcut ekosistemde tahribata, arazi topoğrafyasının değişmesine, doğal bitki ve hayvan topluluklarının zarar görmesine, antropojenik yer şekillerinin (yapay tepeler ve çukurluklar) oluşmasına ve hidrolojik döngüde önemli değişimlere sebep olmaktadır (Özbey 2005). Dolayısıyla işletme sırasında ve sonrasında ortaya çıkan çevresel etkiler; ekolojik, ekonomik ve estetik yönlerden coğrafyayı etkilemektedir (Korkmaz ve ark. 2011).

Sanayi alanında tuğla ve kiremit sektörüne yaptığı katkı neticesinde Türkiye'nin ana üretim bölgelerinden biri olarak değerlendirilen Tekirdağ ilindeki en önemli tuğla ve kiremit üretim alanı, Naip Ovası ve yakın çevresidir. Jeolojik özellikleri, alt yapı ve lojistik durumu bakımından önemli bir hammadde üreticisi olan bu saha, yoğun kullanımdan dolayı son birkaç on yıl içinde madencilik faaliyetlerinin yol açtığı çeşitli dramatik problemlerle karşı karşıya kalmıştır (Özşahin ve ark. 2017a). Bu çalışmada Naip Ovası ve yakın çevresindeki tuğla ve kiremit sektörüne hammadde sağlanan maden ocaklarının mekânsal özellikleri ve ortaya çıkardığ çevresel etkilerinin açıklanması amaçlanmıştır. Çalışma kapsamında sahadaki maden ocaklarının yakın geçmişteki (2012) ve günümüzdeki (2017) durumu, çeşitli türden mekânsal tekniklerle çözümlenmeye çalışılmış ve ortaya çıkan sorunların da tartışılması hedeflenmiştir. Böylece hem Trakya Yarımadası'nın hem de Tekirdağ ilinin en önemli yer şekillerinden biri olan Naip Ovası'nın açık işletme şeklinde uygulanan madencilik faaliyetlerinden ne derecede ve hangi yönde etkilendiği ortaya çıkarılmıştır.

Naip Ovası ve yakın çevresindeki tuğla ve kiremit sektörünü içine alan toprak sanayisinin durumu, daha önce neden olduğu sorunlar ve alınması gereken önlemler konu başlıkları çerçevesinde değişik çalışmalarla gündeme taşınmıştır (Cangir ve ark. 1995; Cangir ve ark. 1996; Cangir ve Boyraz 1997a; Cangir ve Boyraz 1997b). Ancak daha çok mevcut durumun açıklanması şeklinde yürütülmüş bu çalışmalarda, zamansal ve mekânsal ölçekte herhangi bir durum analizi veya karşılaştırma yeterli ölçüde yapılamamıştır. Ayrıca bu çalışmaların tarihleri de oldukça eski olduğu için günümüzdeki durum tam anlamıla anlaşılamamaktadır. Dolayısıyla bu çalışma güncel durumu zamansal ve mekânsal perspektifte ortaya koyarak geleceğe yönelik çıkarımlarda bulunmaktadır. Eskiden beri irdelenen oldukça karakteristik bir örnek dâhilinde hayata geçirilen bu çalışma, tuğla ve kiremit sektörüne ait fabrikaların ve maden ocaklarının zaman içerisinde doğal çevrede nasıl bir değişime ve dönüşüme yol açtığını göstermesi bakımından da önem taşımaktadır.

\section{Çalışma Alanı}

İnceleme sahas1, Türkiye'nin kuzeybatı kesiminde yer alan ve Tekirdağ ili smırları içerisinde bulunan Naip Ovası ve yakın çevresini kapsamaktadır (Şekil 1). Ganos Dağı'nın kuzeydoğu kesiminde konumlanan bu saha, aynı zamanda Marmara Denizi'ne dökülen önemli bir akarsu olan Ana derenin aşağı kesimine karşılık gelmektedir (Şekil 1).

Naip ovası, jeolojik mazide denizin içeriye doğru sokulduğu bir haliç karakterinde iken denizin geri çekilmesini takip eden aşamada akarsular tarafindan getirilen materyallerle doldurulmuş taban seviyesi ovası karakterindedir. Tekirdağ ilinin en önemli tarımsal üretim merkezlerinden biri olan bu sahada, sulamalı şekilde birçok çeşitli tarımsal faaliyetler gerçekleştirilmektedir (Özşahin 2015).

İnceleme alanı, tarımsal kimliğinin yanında tuğla üretim kimliğiyle de ön plandadır. Zira burası, Türkiye'nin en yoğun tuğla ve kiremit üretiminin yapıldığ 1 yerlerden biri olan Tekirdağ ilinde bulunmakta olup, aynı zamanda il içinde de bu tür faaliyetlerin adeta kalbinin attığı noktaya karşılık gelmektedir. 


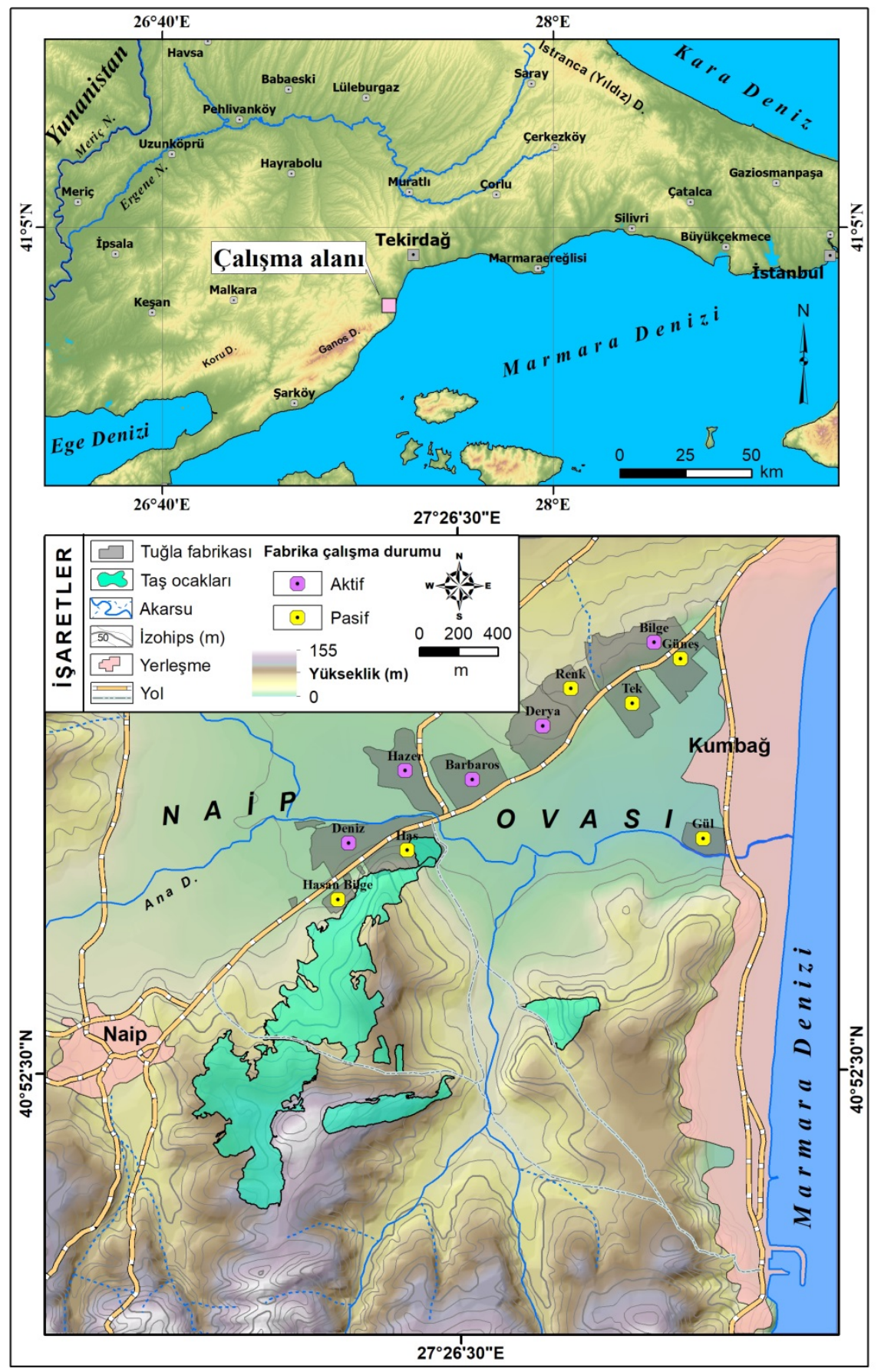

Şekil 1. Lokasyon haritası.

Esasında bu sahadaki tuğla ve kiremit sektörünün geçmişi 19. yüzyllın sonu kadar dayanmaktadır. O dönemde yörede küçük ölçekli tuğla ve kiremit ocağı işletmelerinin bulunduğu bilinmektedir (Özşahin ve ark. 2016a; Özşahin ve ark. 2016b; Özşahin ve ark. 2017b). Özellikle bu civardaki Mera, Kurnalı ve Karabayır mevkii şeklinde adlandırlan üç noktada tuğla ve kiremit ocağı faaliyetlerinin aktif bir şekilde işletildiği kayıtlara geçmiştir. Ayrıca bu işletmelerden yılda 62.000 adet tuğla ve kiremit elde edildiği de bildirilmiştir (Edirne Vilayet Salnamesi 1309; Ekin ve Kanal 2014). Ancak Naip Ovası ve yakın çevresinde tuğla ve kiremit sektöründeki modern anlamda esas gelişim, 1970'li yıllardan sonra başlamışıtır. Bu başlangı̧̣ evresini takip eden yıllarda sahada birden çok fabrika kurulup kapandığı gibi, bazı fabrikalarda çeşitli nedenlerle isim değişikliğine gitmiştir. Günümüzde aynı sahada aktif olarak çalşsan 5 adet fabrika bulunmaktadır (Şekil 1; Cizelge 1). Ancak son yıllarda bu sahada artan sektör yığınlı̆̆ neticesinde yöre adeta bir "Tuğla ve Kiremit Üretim Bölgesi” vasfi kazanmıştır. 
Çizelge 1. Çalışma alanındaki tuğla fabrikaları ve genel özellikleri

\begin{tabular}{lcc}
\hline Tuğla Fabrikası & Çalışma Durumu & Yakıt Durumu \\
\hline Bilge & Aktif & Kömür \\
Derya & Aktif & Doğal gaz \\
Barbaros (Marmara) & Aktif & Kömür \\
Hazer (Ferhat, Başak, Salmo, Dinç, Zela) & Aktif & Kömür \\
Deniz & Aktif & Kömür \\
Güneş & Pasif & Kömür \\
Renk & Pasif & Kömür \\
Tek & Pasif & Kömür \\
Has & Pasif & Kömür \\
Hasan Bilge & Pasif & Kömür \\
Gül & Pasif & Kömür \\
Tolga & Pasif & Kömür \\
\hline
\end{tabular}

\section{Materyal ve Yöntem}

Çalışmanın ana materyali, arazi çalışmaları eşliğinde toplanan yersel veriler ve yüksek çözünürlüklü $(1 \mathrm{~m})$ ortofotolardır. Taş ocaklarının çevresel etkilerini daha somut bir şekilde açıklamak ve bu sahada gerçekleştirilen antropojenik faaliyetlerin doğal çevrede bıraktığı kirliliğe ait fikir edinmek adına sahanın muhtelif kesimlerinden alınan su ve toprak örneklerinden oluşan yersel veriler, arazi gözlemleri sırasında yapılan görüşme ve gözlemlerle zenginleştirilmiştir. Su ve toprak örneklerinin alımı sırasında çalışma alanının tamamını yansıtacak ölçüde veri toplanmasına gayret edilmiş ve öncelikle aktif olarak hammadde üretiminin yapıldığı alanlar seçilmeye çalıșılmıştır. Bu bağlamda 5 adet su ve 6 adet toprak örneği alınmıștır. Çalışmanın maddi bütçesi el vermediğinden dolayı örneklem sayısı da düşük tutulmuştur. Ancak alanı en iyi temsil edecek şekilde örnekleme yapılmıştır. Alınan örneklerin kirlilik durumları, Keşan Ticaret Borsası Toprak Laboratuvarında yaptırılan ağır metal analizlerine dayalı olarak yorumlanmıştır. Ayrıca kirlilik durumunun mekânsal olarak nasıl bir dağılım gösterdiğini haritalamak için IDW (Ters Mesafe Ağırlıklı Enterpolasyon) tekniğine dayalı enterpolasyon yöntemi kullanılmışır (Bostan 2017).

Sahadaki taş ocaklarının zamansal ve mekânsal olarak geçirdiği alansal ve hacimsel değişimler, eski ve güncel tarihli ortofotolar kullanılarak üretilen sayısal yükselti modelleri üzerinden hesaplanmış ve görüntü analizleriyle de yorumlanmıştır. Bunun için sahanın 2012 yılındaki durumunu gösteren verileri Harita Genel Komutanlı̆̆ı'ndan, 2017 yılına ait verileri ise insansız hava aracı (IHA) tabanlı yöntemler kullanılarak elde edilen ortofoto görüntülerinden sağlanmıştır. Bu dijital hava fotoğrafları, standart bir görüntü çözünürlüğü (100 cm) kullanılarak düzenlenmiştir. Çalışmanın diğer tematik haritaları ise CBS (Coğrafi Bilgi Sistemleri) tekniklerine dayalı olarak ArcGIS 10.5 programında çizilmiştir. Elde edilen veriler, insan ve mekân etkileşimi boyutuyla değerlendirilmiş tir.

\section{Bulgular ve Tartıșma}

İnşaat sektöründe yaygın olarak kullanılan ve ham maddesi kil olan ürünler, dünya tarihinde imalat1 yapılan ilk yap1 malzemelerini oluşturmaktadır (Akman 2003). Bu ürünleri elde etmek için başlatılan girişimler, malzeme teknolojisinin gelişmesine neden olduğu gibi, aynı zamanda pişmiş kilden ve çimentodan gereçler sanayisinin bir alt kolu olan Tuğla ve Kiremit Sektörü adında bir sanayi dalının da ortaya çıkmasına yol açmıştır (Anonim 2007).

Türkiye'de çok sayıda üretim birimi olan bu sektör, aynı zamanda oldukça ciddi bir üretim yapısına sahiptir. Nitekim TUKDER (Tuğla ve Kiremit Üreticileri Derneği) verilerine göre, Türkiye'nin toplam tuğla üretim kapasitesinin y1llk 7 milyar 353 milyon adet ve kiremit üretim kapasitesinin ise 717 milyon 500 bin tondur (Anonim 2014). Türkiye çapında faal durumda 320 civarında tuğla ve kiremit fabrikasıyla temsil edilen bu sanayi dalı, bazı alanlarda ciddi mekânsal yoğunlaşmaya maruz kalmaktadır. Hatta bu olgu, bazı yerlerin “Tuğla ve Kiremit Üretim Bölgeleri” haline dönüşmesine yol açmıștır. Bu tür sahalardan birisi de Tekirdağ ilidir. Tuğla ve kiremit sektöründe Türkiye'nin ana üretim bölgelerinden biri olarak değerlendirilen bu ilin sosyo-ekonomik gelişiminde sanayinin bilhassa da tuğla ve kiremit sektörünün önemli katkıları bulunmaktadır (Anonim 2001). 
Tuğla ve kiremit üretiminin tamamının özel sektör arayıcılığıyla gerçekleştirildiği Tekirdağ ilinde (Şişman ve ark. 2006) resmi kayıtlara göre faaliyet gösteren 20 adet işletme vardır (Anonim 2014). Bu işletmelerin büyük çoğunluğu (14 adet) Süleymanpaşa ilçesince bulunmaktadır (Anonim 2001). İlçenin toplam tuğla üretim kapasitesinin y1llık 488 milyon 500 bin adet, kiremit üretim kapasitesinin de 12 milyon ton olduğu tespit edilmiştir (Anonim 2001).

Süleymanpaşa ilçesinde tuğla ve kiremit sektörüne ait fabrikaların ve maden ocakların en yoğun olduğu yer, Naip Ovası ve yakın çevresidir (Şekil 2). Bu sahada tuğla ve kiremit sektörünün gelişiminde ve yoğunlaşmasında bazı faktörler etkili olmuştur. Aslında bu faktörler, ekonomik anlamda bir ürünün ticaretinin yapılmasında rol oynayan başlıca unsurlar olarak değerlendirilen hammadde, üretim ve pazar üçlüsüdür (Hämäläinen ve Inkinen 2017).

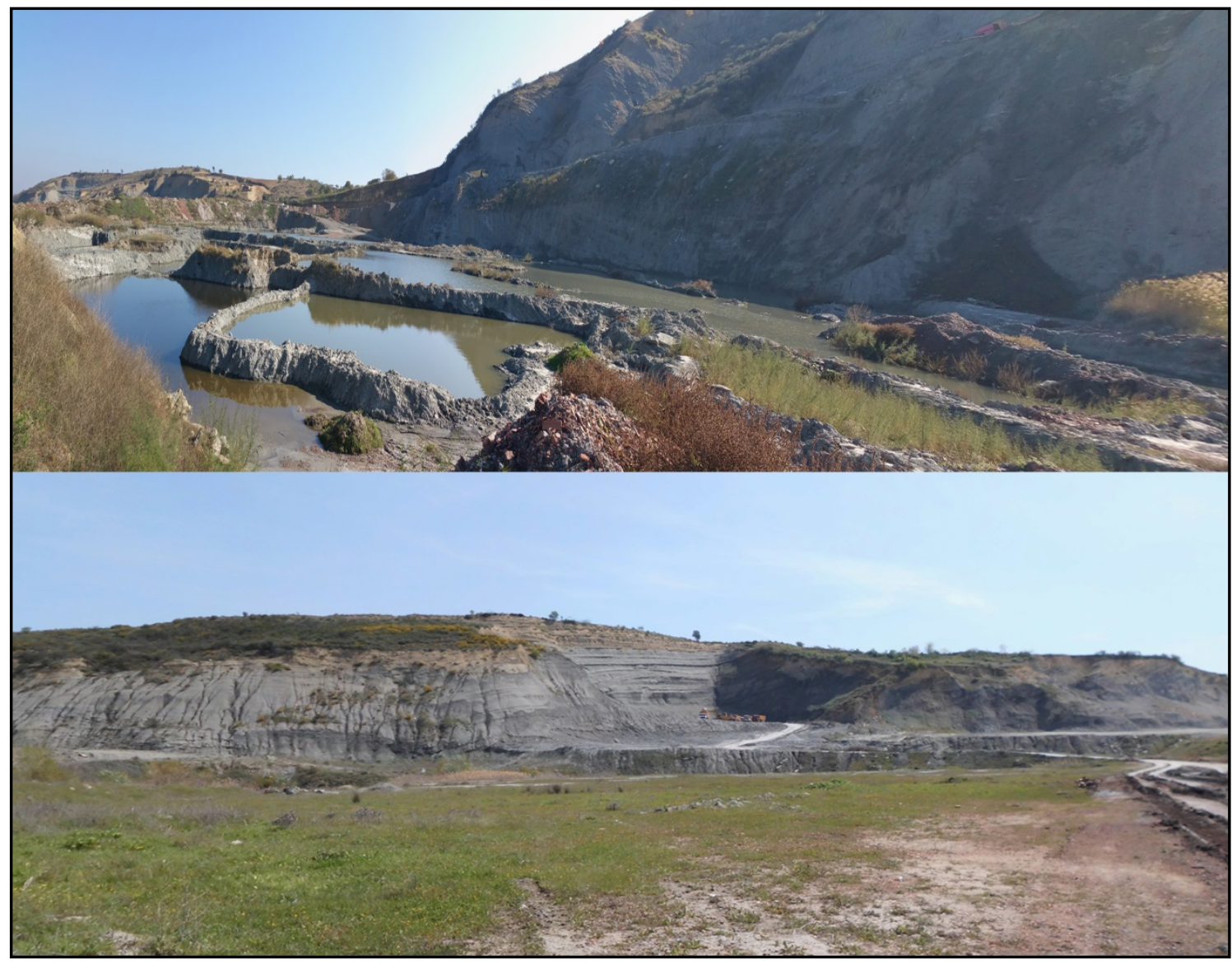

Şekil 2. Çalışma alanında maden ocaklarından bir görünüm.

Bu faktörlerin ilki ve belki de en önemlisi hammaddedir. Değişik yaş ve türde litolojik birimlerin yayıllş̧ gösterdiği çalışma alanında, Üst Eosen-Alt Oligosen yaşındaki Yenimuhacir (Mezardere) Formasyonu tuğla ve kiremit yapımına uygun kayaç topluluğuna sahiptir (Okay ve ark. 2008). Zira ovanın güney kesimindeki yaygın olan bu birimin ana litolojisini oluşturan şeyl, tuğla ve kiremit üretiminde kullanılan en yaygın kayaçtır (Şekil 3). Ayrıca bu formasyonun ortalama kalınlığının 1000 m'den fazla olması da işletmeye uygun miktarda malzemenin sağlanması için önemli bir avantajdır. Dolayısıyla sahanın jeolojik yapısının bu türden sanayi ürünlerinin elde edilmesine uygun hammadde özellikleri ihtiva ettiği için popüler olduğu anlaşılmaktadır. 


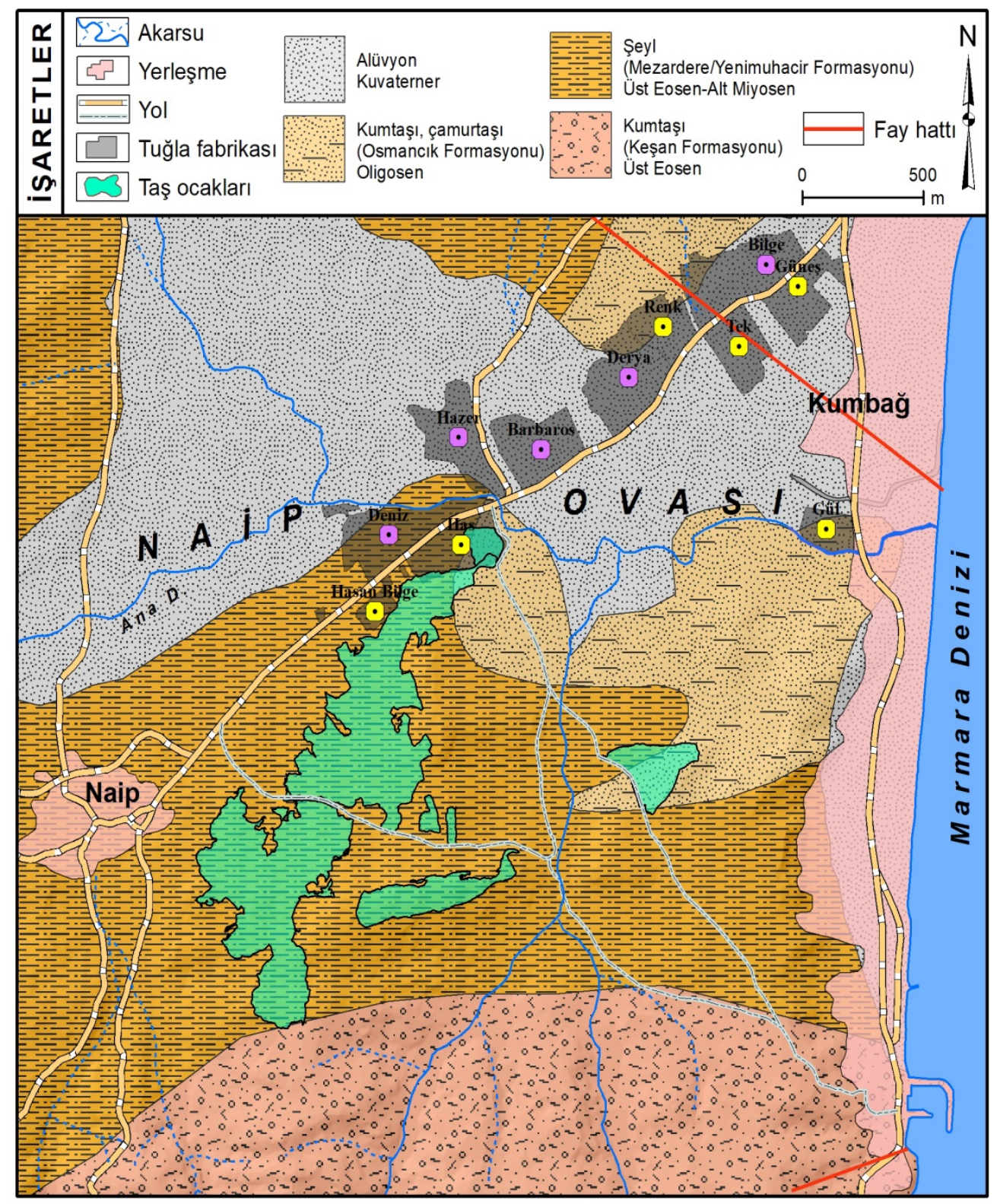

Şekil 3. Çalışma alanının jeoloji haritası.

Diğer yandan Naip Ovası ve yakın çevresinin alt yapı imkânları ve pazara yakınlığı da tuğla ve kiremit sektörünün bu yörede bulunmasında belirleyici olmuştur (Anonim 2014). Ulaşım imkânlarının çeşitlendiği ve geliştiği bir sahada bulunan Naip Ovası ve yakın çevresi, aynı zamanda başta İstanbul olmak üzere Edirne, Kırklareli, Keşan ve Gelibolu gibi önemli pazarlara da yakın bir konumda bulunmaktadır. Bu durum tuğla ve kiremit sektörünün gelişmesini hızlandırmıştır. Zira burada üretilen ürünlerin tamamı Trakya Yarımadası içerisinde pazarlanmaktadır. Hatta bu ürünler İstanbul'un Anadolu yakasına dahi geçmemektedir. Bütün bu altyapı ve lojistik üstünlükler bu türden sanayi ürünlerinin daha avantajı bir konum kazanmasına yardımcı olmuştur.

Tuğla ve kiremit sektörü bakımından Naip Ovası ve yakın çevresinin sunduğu bütün bu imkânlar neticesinde, sahadaki taş ocakların yatayda ve dikeyde mekânsal büyümesi her geçen gün artarak devam etmektedir. Harita analizlerine göre 2012 yılında 58.05 ha alan kaplayan bu ocakların, 2017 y1lında 71.83 ha alanda yayılış gösterdiği tespit edilmiştir. Keza bu ocakların hacmi de ilgili yıllarda sırasıla $29.877 .873 \mathrm{~m}^{3}$ 'ten 64.438 .075 $\mathrm{m}^{3}$ 'e büyümüştür. Buna göre 5 yıl yıl içinde tuğla ocaklarında 13.43 ha alansal, $34.560 .202 \mathrm{~m}^{3}$ 'te hacimsel genişlemenin olduğu anlaşılmıştır (Çizelge 2; Şekil 4). Dolayısıyla tuğla ocaklarında izlenen bu mekânsal büyüme temposu, işletme sahiplerinden alınan bilgiler 1şı̆̆ında değerlendirildiğinde 2020 y1lında ocak alanlarının yaklaşık 100 ha'lık bir araziyi işgal edeceği tahmin edilebilir (Şekil 4). 
Çizelge 1. Çalışma alanındaki tuğla ocaklarında 2012-2017 yıllarında yaşanan alansalve hacimsel değişimler

\begin{tabular}{cccc}
\hline Yll & Alan (ha) & Hacim $\mathbf{( m}^{\mathbf{3}}$ ) & Ton \\
\hline 2012 & 58.40 & 29.877 .873 & 28.682 .758 \\
2017 & 71.83 & 64.438 .075 & 61.860 .552 \\
Değişim & 13.43 & 34.560 .202 & 33.177 .794 \\
Ortalama & 65.12 & 47.157 .974 & 45.271 .655 \\
\hline
\end{tabular}

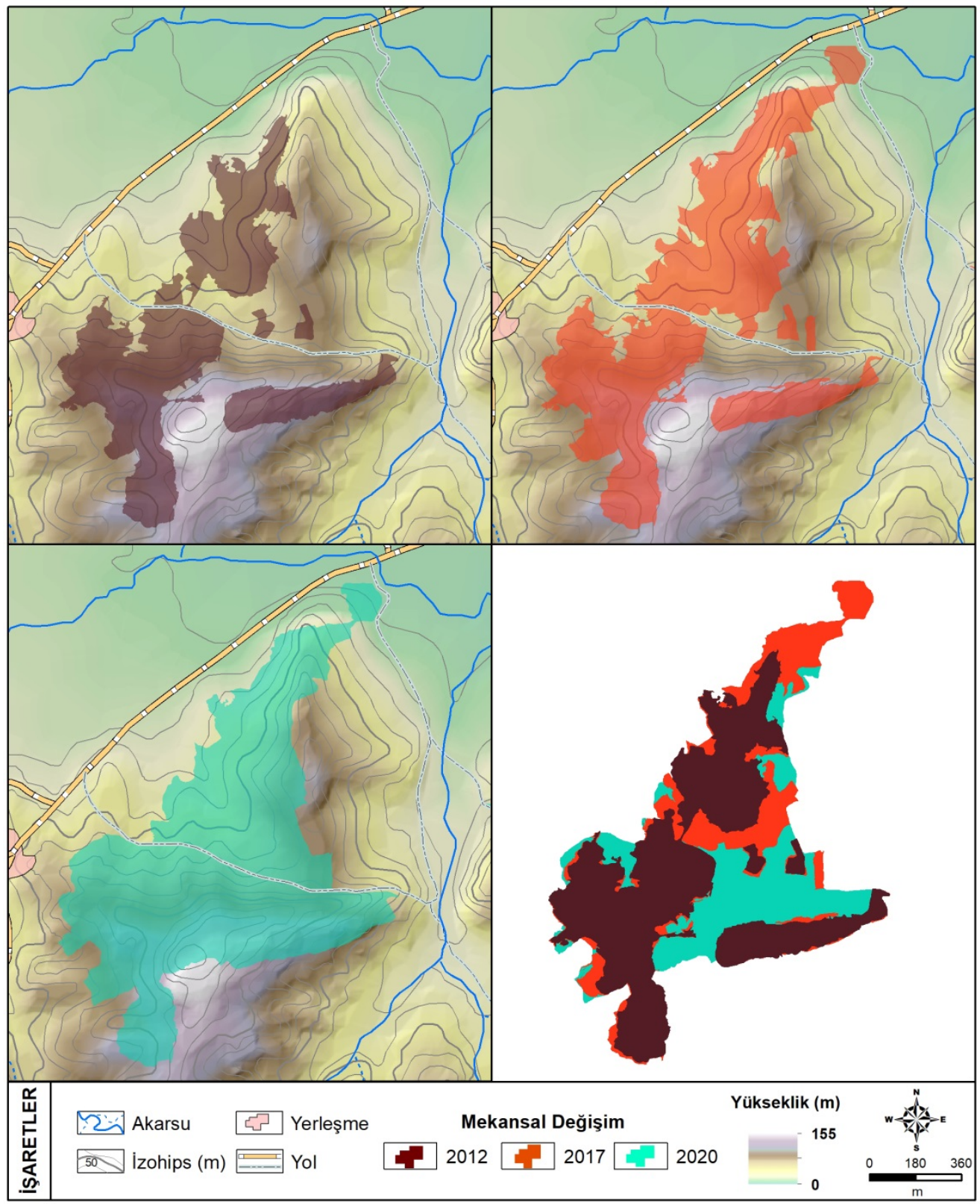

Şekil 4. Çalışma alanındaki taş ocaklarının zamansal ve mekânsal değişim haritası.

Çalışma alanında günümüze yakın dönemde tuğla ve kiremit sektöründeki gelişmelere bağlı olarak maden ocağ 1 işletmelerinde yaşanan alansal ve hacimsel büyümeler neticesinde; kirlilik ve doğal peyzajın bozulmas1, arazi kullanımının değişmesi, kütle hareketleri ve erozyon gibi çevre sorunları ortaya çıkmıştır (Şekil 5; 6). Zaten açık işletmecilik şeklinde yapılan madencilik faaliyetlerinin, coğrafi çevrede birçok soruna yol açtı̆̆ bilinmektedir (Özşahin ve ark. 2017a). 


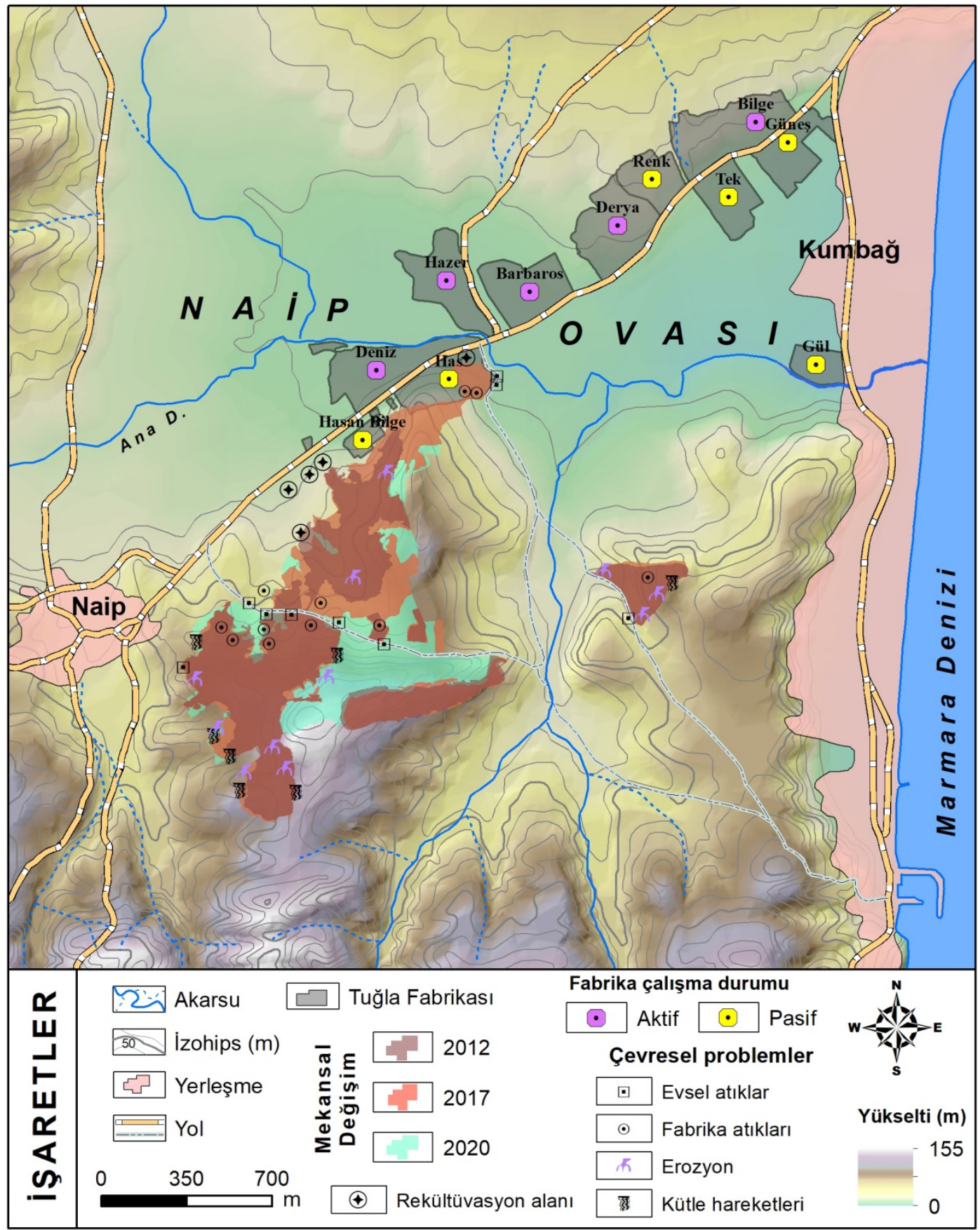

Şekil 5. Çalışma alanındaki taş ocaklarının çevresel problemler haritası. 


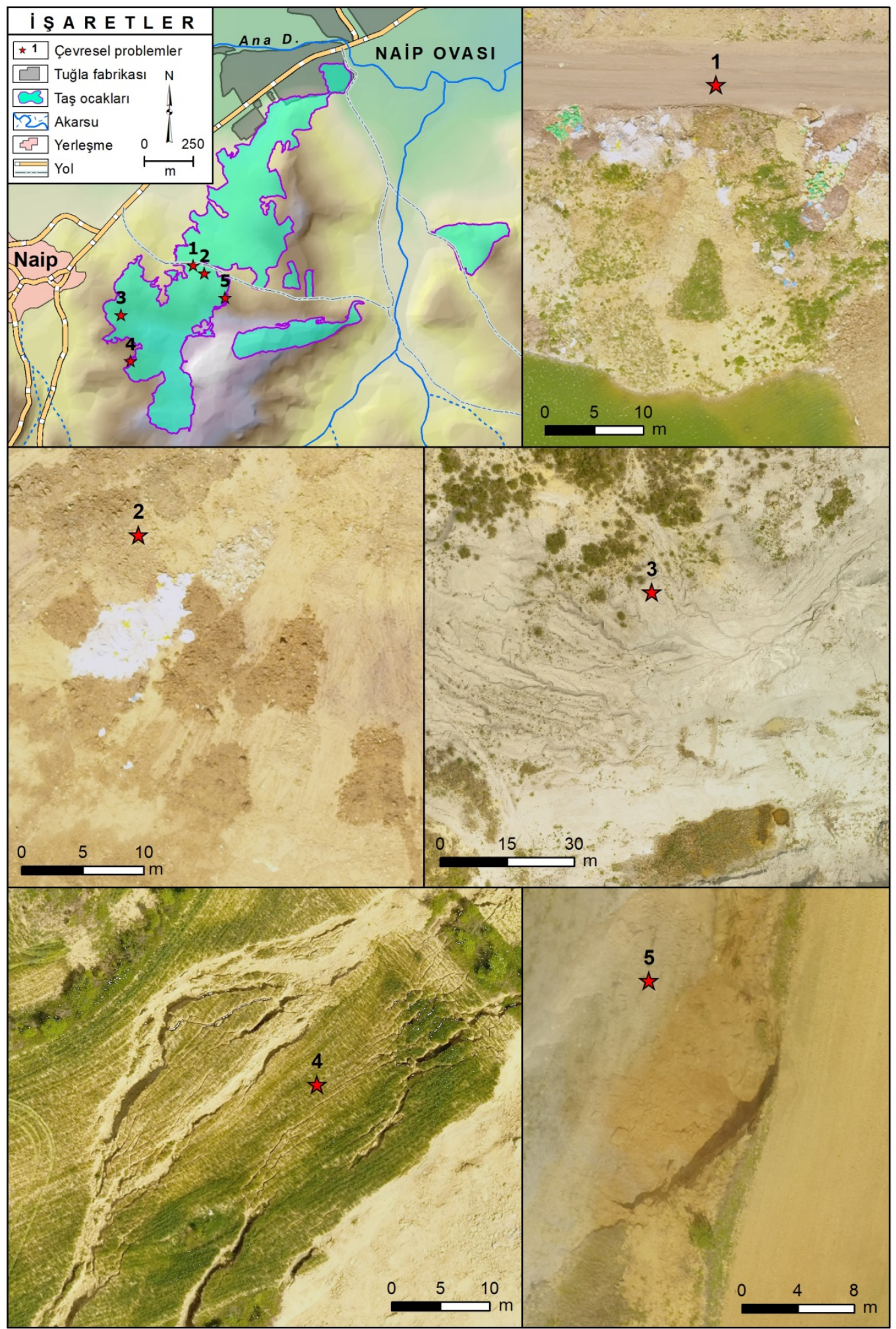

Şekil 6. Çalışma alanındaki başlıca çevresel problemler.

Çalışma alanında yapılan madencilik faaliyetleri neticesinde yaşanan en temel problem, çevre kirliliğidir (Şekil 5; 6; 7). Taş ocaklarına kontrolsüz bir biçimde atılan hem fabrika hem de yakın yerleşmelerdeki atıklar veya iş makinelerinden kaynaklanan çevre kirliliği özellikle ocak alanlarında hammadde alımı sebebiyle oluşan yapay çukurluklarda daha fazla yoğunlaşmaktadır. Bu durum zamanla su, toprak ve görüntü kirliliğine yol açmaktadır (İnci 2014; Yıldız 2014). Gerçekten de çalışma alanından rastgele alınan su ve toprak örneklerinin ağır metal yoğunluğunun mekânsal dağılışı, özellikle hammadde üretimi için aktif olarak kullanılan sahalarda önemli oranda ağır metal birikiminin olduğunu göstermiştir (Çizelge 3; Şekil 8). Ayrıca gerek hammaddenin 
çıkarılması ve taşınması esnasında çevreye yayılan toz ve gürültü gerekse kömürle çalışan fabrika bacalarından çıkan dumanlar insan sağlı̆̆ını tehdit etmektedir. Aynı zamanda bütün bu sorunlar doğal peyzajın bozulmasına da sebep olmaktadır (Asurve Alphan 2018).

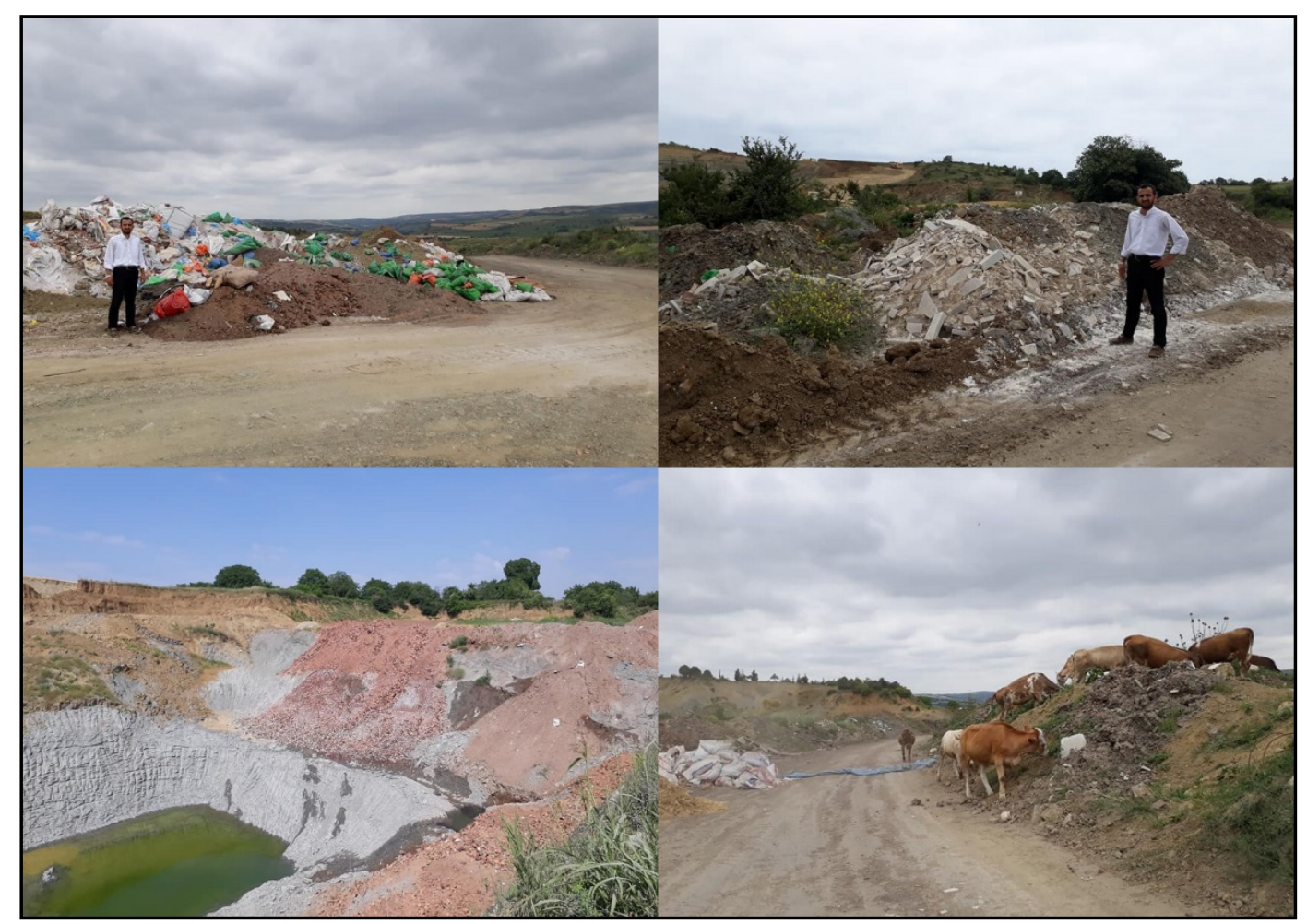

Şekil 7. Çalışma alanındaki başlıca çevresel problemlerden bir görünüm.

Çalışma alanında yapılan madencilik faaliyetleri neticesinde yaşanan en temel problem, çevre kirliliğidir (Şekil 5; 6). Taş ocaklarına kontrolsüz bir biçimde atılan hem fabrika hem de yakın yerleşmelerdeki atıklar veya iş makinelerinden kaynaklanan çevre kirliliği özellikle ocak alanlarında hammadde alımı sebebiyle oluşan yapay çukurluklarda daha fazla yoğunlaşmaktadır. Bu durum zamanla su, toprak ve görüntü kirliliğine yol açmaktadır (İnci 2014; Yıldız 2014). Gerçekten de çalışma alanından rastgele alınan su ve toprak örneklerinin analizi sonucunda bazı ağır metallerde ciddi oranda artışların yaşandığı tespit edilmiştir. Nitekim Su 1 örneğinde Kobalt ve Mangan, toprak örneklerin tamamında ise Nikel, Demir ve Mangan oranları sınır değerleri aşmışıtır (Çizelge 3; 4). Dolayısıyla çalışma alanındaki ağır metal yoğunluğunun mekânsal dağılışı, özellikle hammadde üretimi için aktif olarak kullanılan sahalarda önemli oranda ağır metal birikiminin olduğunu göstermiştir (Çizelge 4; Şekil 8). Ayrıca gerek hammaddenin çıkarılması ve taşınması esnasında çevreye yayılan toz ve gürültü gerekse kömürle çalışan fabrika bacalarından çıkan dumanlar insan sağlığını tehdit etmektedir. Aynı zamanda bütün bu sorunlar doğal peyzajın bozulmasına da sebep olmaktadır.

Çizelge 3. Türkiye Toprak ve Su kirliliği kontrolü yönetmeliklerine göre çalışma alanında ölçümü yapılan ağır metallerin sinır değerleri

\begin{tabular}{ccc}
\hline Ăgır Metal (ppm) & Su & Toprak \\
\hline Krom (Cr) & 0.2 & 100 \\
Vanadyum (V) & 0.2 & 256 \\
Kurşun (Pb) & 0.01 & 50 \\
Nikel (Ni) & 0.02 & 30 \\
Kobalt (Co) & 0.01 & 80 \\
Demir (Fe) & 0.3 & 4.5 \\
Mangan (Mn) & 0.1 & 70 \\
Bakır (Cu) & 0.02 & 50 \\
Çinko (Zn) & 0.2 & 150 \\
\hline
\end{tabular}


Çizelge 4. Çalışma alanındaki maden ocaklarından alınan su ve toprak örneklerinin ağır metal içerikleri

\begin{tabular}{|c|c|c|c|c|c|c|c|c|c|}
\hline Örnek & $\begin{array}{c}\text { Krom } \\
\text { (Cr) } \\
\text { (ppm) } \\
\end{array}$ & $\begin{array}{c}\text { Vanadyum } \\
\text { (V) } \\
(\mathrm{ppm}) \\
\end{array}$ & $\begin{array}{c}\text { Kurşun } \\
\text { (Pb) } \\
\text { (ppm) }\end{array}$ & $\begin{array}{c}\text { Nikel } \\
(\mathrm{Ni}) \\
(\mathrm{ppm}) \\
\end{array}$ & $\begin{array}{c}\text { Kobalt } \\
\text { (Co) } \\
(\mathrm{ppm}) \\
\end{array}$ & $\begin{array}{c}\text { Demir } \\
\text { (Fe) } \\
\text { (ppm) }\end{array}$ & $\begin{array}{c}\text { Mangan } \\
\text { (Mn) } \\
\text { (ppm) }\end{array}$ & $\begin{array}{c}\text { Bakir } \\
(\mathrm{Cu}) \\
(\mathrm{ppm}) \\
\end{array}$ & $\begin{array}{c}\text { Çinko } \\
\text { (Zn) } \\
\text { (ppm) }\end{array}$ \\
\hline Su 1 & 0.001 & 0.057 & 0.007 & 0.002 & 5.478 & 0.045 & 3.589 & 0.003 & 0.011 \\
\hline Su 2 & 0.002 & 0.060 & 0.004 & 0.002 & 0.003 & 0.018 & 0.001 & 0.003 & 0.016 \\
\hline Su 3 & 0.009 & 0.048 & 0.017 & 0.004 & 0.0009 & 0.003 & 0.001 & 0.001 & 0.024 \\
\hline $\mathrm{Su} 4$ & 0.002 & 0.048 & 0.001 & 0.001 & 0.002 & 0.001 & 0.001 & 0.001 & 0.010 \\
\hline Su 5 & 0.007 & 0.031 & 0.009 & 0.011 & 0.0008 & 0.0007 & 3.137 & 0.0007 & 0.024 \\
\hline Toprak 1 & 89.88 & 145.97 & 12.14 & 150.13 & 21.63 & 18573.05 & 461.49 & 42.35 & 54.02 \\
\hline Toprak 2 & 81.78 & 166.61 & 14.09 & 121.062 & 18.47 & 17225.12 & 588.87 & 34.79 & 46.57 \\
\hline Toprak 3 & 86.65 & 164.33 & 19.39 & 139.474 & 19.21 & 18066.92 & 465.11 & 39.90 & 54.62 \\
\hline Toprak 4 & 80.52 & 176.39 & 9.46 & 130.991 & 19.40 & 17005.87 & 495.73 & 37.69 & 47.93 \\
\hline Toprak 5 & 85.78 & 183.64 & 10.73 & 123.482 & 19.74 & 17640.97 & 524.61 & 36.88 & 47.63 \\
\hline Toprak 6 & 75.77 & 173.58 & 13.10 & 111.268 & 19.73 & 16680.45 & 480.03 & 32.81 & 43.97 \\
\hline
\end{tabular}

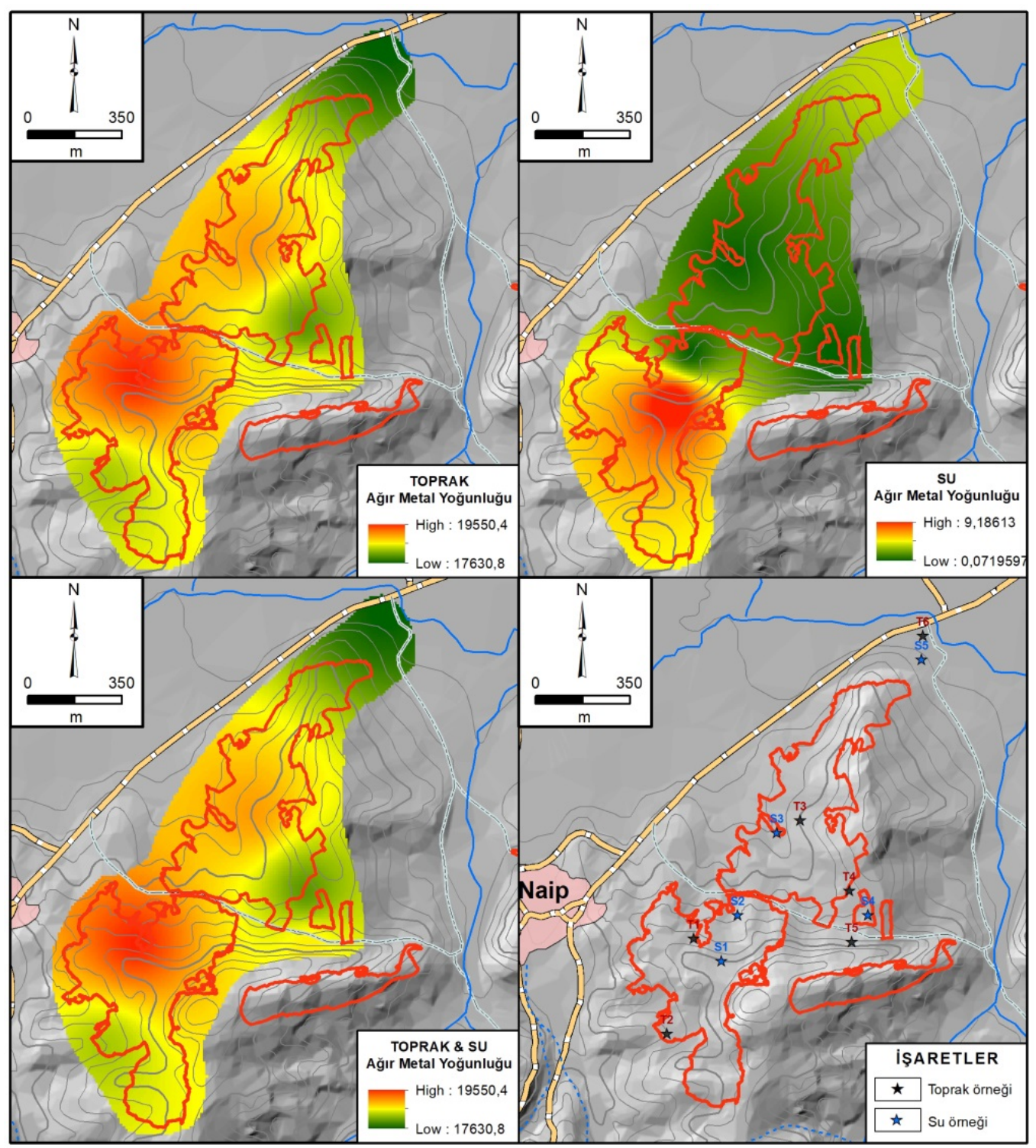

Şekil 8. Çalışma alanındaki maden ocaklarından alınan su ve toprak örneklerinin ağır metal içeriklerinin mekânsal dağılış yoğunluğu haritası. 
Çalışma alanındaki madencilik faaliyetleriyle bağımlı bir şekilde beliren başlıca problemlerden bir başkası, arazi kullanımının değişmesidir (Şekil 4; 5). Ağırlıklı olarak olumsuz bir biçimde gelişen bu süreç, özellikle verimli tarım alanların yok olmasına yol açmışır. Hatta birçok araştırmacı tarafindan verimli tarım arazilerinin tarım dışı amaçlarla kullanılmasının bu bölgedeki en önemli problem olduğu ileri sürülmüştür (Cangir ve ark. 1995; Cangir ve ark. 1996; Cangir ve Boyraz 1997a; Cangir ve Boyraz 1997b; İnan 2006; Polat 2014). Gerçekten de çalışma alanında hem fabrika hem de taş ocaklarının önemli bir kısmı I. sınıf tarım arazilerini işgal etmiş durumdadır. Diğer kısmı ise II. ve III. sınıf tarım arazileri üzerinde yayılış göstermektedir. Ayrıca madencilik faaliyetlerinden kaynaklanan toz ve dumanın kültür bitkileri üzerindeki olumsuz etkisi ile hammadde alımı neticesinde sahadaki doğal drenaj sisteminin ve taban suyu düzeyinin bozulması ve kaybolması gibi olumsuzluklar da tarımsal kaynaklı diğer sorunlardır (Cangir ve Boyraz 1997b).

Diğer yandan sahadaki arazi kullanımındaki değişimler bazı yerlerde çok az da olsa olumlu bir şekilde dönüşüm geçirmiştir. Nitekim taş ocaklarından hammadde alımının bittiği bazı kesimlerin işletmeci tarafından tarım alanına dönüştürülmesi (Rekültüvasyon alanı) bunun en karakteristik örneğidir (Şekil 4; 5). Zaten Türkiye'deki maden kanunu uygulama yönetmenliğine göre tarım alanlarındaki madencilik faaliyetlerinde maden ruhsat sahibinin arama faaliyeti sonrası, faaliyette bulunduğu bölgeleri çevre ile uyumlu hale getirmesi zorunluluğu vardır. Ayrıca izin verilen maden sahasının üzerinde toprak olması durumunda ise bu toprakların sıyrılarak bir yere depolanması ve faaliyetin tamamlanmasını takiben rekültüvasyon çalışmalarında kullanılması gerektiği bildirilmiştir (Anonim 2005).

Çalışma alanındaki madencilik faaliyetleri sonucunda karşılaşan diğer bir problem, kütle hareketleri ve erozyondur. Gerçekten de 2012-2017 yılları arasında sahada yamaç stabilitesinin bozulduğu muhtelif kesimlerde değişik türden heyelan ve toprak akması olayları gerçekleşmiştir (Şekil 4; 5). Yine aynı zaman aralığında beliren erozyon yarıntılarında da önemli miktarda büyümenin olduğu açık bir şekilde izlenmektedir (Şekil 4; 5).

Çalışma alanındaki madencilik faaliyetlerinin yoğunluğuna paralel olarak 2012-2017 zaman aralığında izlenen değişim ve dönüşümler, gelecek yıllarda yaşanacak gelişmelere gebedir. Bu bağlamda yakın gelecekte maden ocağ 1 işletmelerinde mekânsal olarak hem yatayda hem de dikeyde önemli büyümeler gerçekleşeceği tahmin edilmektedir. Ancak bu büyümelerin fabrika sahalarında kendini yeterince göstermeyeceği düşünülmektedir. Gerekli önlemler alınmadığı takdirde yukarıda açıklanan sorunların devam edeceği aşikârdır. Bunun için sanayileşmeye yönelik adımların daha çevreci ve sürdürülebilir ölçüde atılması elzemdir. Nitekim önceden beri Tekirdağ gerçekleştirilen sanayileşme çabalarında, çevre boyutunun en üst seviyede gözetildiği taktirde daha planlı uygulamalarla ilerlemenin sağlanabileceğini vurgusu yapılmaktadır (İncekara 2006).

\section{Sonuç}

Çalışma sonuçları, Naip Ovası ve yakın çevresindeki taş ocaklarında zaman içinde hem alansal yoğunlaşmanın hem de mekânsal büyümenin yaşandığını göstermiştir. Hammadde, üretim ve Pazar gibi unsurlar alansal yoğunlaşmayı, tuğla ve kiremit ihtiyacının artmasına paralel olarak taş ocaklarından daha fazla malzeme temin edilmesi de mekânsal büyümeyi ortaya çıkarmıştır. Kontrolsüz bir biçimde gerçekleşen bu değişimler ve dönüşümler, ekolojik, ekonomik ve estetik yönlerden coğrafyayı şekillendiren farklı çevre sorunlarına kapı aralamıştır. Bu sorunlar; kirlilik ve doğal peyzajın bozulması, arazi kullanımının değişmesi, kütle hareketleri ve erozyondur. Özellikle hammadde üretimi için aktif olarak kullanılan sahalarda bazı ağır metallerde (Kobalt, Mangan, Nikel ve Demir) sınır değerlerin üzerinde gerçekleşen artışlar neticesinde yer yer su ve toprak kirliliğ belirmeye başlamıştır. Ortaya çıkan bu sorunların çözümü için öncelikle sürdürülebilir bir planlamanın yapılması ve aktif olarak faaliyet gösteren taş ocaklarının ayrıntılı ÇED raporlarının hazırlanması gerekmektedir. Aksi takdirde yakın gelecekte Naip Ovası ve yakın çevresindeki hassas ekosistemlerde geri dönüşü olmayan kayıplar şeklinde muhtemel sorunların ortaya çıkması kaçınılmaz olacaktır. Ayrıca bu çalışma doğal çevre değişimlerinin ve sorunlarının tespitinde ve izlenmesinde, mekânsal teknolojilerin kullanılabileceğini göstermiştir.

\section{Kaynaklar}

Akman MS (2003). Yapı malzemelerinin tarihsel gelişimi. TMH-Türkiye Mühendislik Haberleri. 426 - 2003/4: 30-36.

Anonim (2001). Taş ve Toprağa Dayalı Ürünler Sanayii Özel İhtisas Komisyonu Raporu (Refrakter). DPT. 2551 - ÖİK. 567, Sekizinci Beş Yıllık Kalkınma Planı, Ankara. http://ekutup.dpt.gov.tr/ii imalatsa/tastopra/oik567.pdf (Erişim Tarihi: 07 Aralık, 2017). 
Anonim (2005). Maden Kanunu: Kanun Numaras1 3213, Kabul Tarihi 4/6/1985, Yayımlandığ1 Resmi Gazete: Tarih: 15/6/1985, Sayı: 18785, Yayımlandığ1 Düstur: Tertip: 5 Cilt: 24, Sayfa: 446.

Anonim (2007). Tuğla ve kiremit sanayi bilgileri. Tuğla ve Kiremit Sanayicileri Derneği, http://www.tukder.org/. (Erişim tarihi: 22 Mayıs, 2018).

Anonim (2014). Tuğla ve kiremit fabrikalarında çalışma koşullarının iyileştirilmesine yönelik programlı teftiş sonuç raporu. Çalışma ve Sosyal Güvenlik Bakanlığı İş Teftiş Kurulu Başkanlığı, Ankara.

Asur F, Alphan H (2018). Görsel Peyzaj Kalite Değerlendirmesi ve Alan Kullanım Planlamasına Olan Etkileri. YYÜ TAR BILL DERG. 28 (1): 117-125.

Borand MN (2012). Açık ve kapalı maden işletmeciliğinde çevresel etki. Madencilikte Özel Konular II Ders Projesi, İstanbulTeknik Üniversitesi Fen Bilimleri Enstitüsü Kimya Mühendisliği ABD, İstanbul.

Bostan P (2017). Basic Kriging Methods in Geostatistics. YYÜ TAR BILL DERG. 27 (1): 10-20.

Cangir C, Yüksel O, Taşbaşı A (1995). Tekirdağ'da toprak sanayiinin tarım topraklarında yarattığı sorunlar ve alternatif alanların durumu, s.C-1/C-9, İçinde: İlhan Akalan Toprak ve Çevre Sempozyumu Cilt II, Munsuz N, Ünver İ, ve Çaycı G (editörler), Ankara Üniversitesi Ziraat Fakültesi Halkla İlişkiler ve Yayın Ünitesi, Yayın No:7, Ankara.

Cangir C, Yüksel O, Boyraz D (1996). Trakya'da toprak sanayinin yarattığ 1 sorunlar ve bu sektörde alınması gerekli önlemler. İçinde: Trakya'nın Bugünü ve Geleceği İçin Trakya'da Sanayileşme ve Çevre Sempozyumu, 3-6 Ocak 1996, TMMOB Makine Mühendisleri Odas1 Edirne Şubesi Yayın No:183, Çorlu, Türkiye, s. 303-317.

Cangir C, Boyraz D (1997a). Trakya'da amaç dışı arazi kullanımı ve kırsal arazi sınıflaması. İçinde: I. Trakya Toprak ve Gübre Sempozyumu Bildiriler Kitabı, Tekirdağ Ziraat Fakültesi Toprak Bölümü Gübre Üreticileri Derneği, 20-22 Ekim 1997, Tekirdağ, Türkiye, s. 19-28.

Cangir C, Boyraz D (1997b). Tekirdağ'da toprak sanayinin sorunları ve Işıklar-Naip-Kumbağ köyleri örneği. İçinde: I. Trakya Toprak ve Gübre Sempozyumu Bildiriler Kitabı, Tekirdağ Ziraat Fakültesi Toprak Bölümü Gübre Üreticileri Derneği, 20-22 Ekim 1997, Tekirdağ, Türkiye, s. 332-343.

Dumlu S (2014). Açık işletmelerde şev açıs1, basamak yüksekliği ve genişliğinin belirlenmesi ve iş güvenliği açısından önemi. İş Müfettişi Yardımcılığı Etüdü, T.C. Çalışma ve Sosyal Güvenlik Bakanlığ İş Teftiş Kurulu Başkanlı̆̆ 1 , Bursa.

Edirne Vilayeti Salnamesi (1309). Vilayet matbaas1, Edirne.

Ekin Ü, Kanal H (2014). Tekfurdağı Sancağı'nın sosyal ve ekonomik yapısı (1890-1902). HUMANITAS. 4: 109-127.

Goergen H, Hüpp H, Stolu R D (1981). The logical in planning an opencast mine. Bilimsel Madencilik Dergisi. 20 (2): 5-18.

Hämäläinen E, Inkinen T (2017). How to generate economic and sustainability reports from big data? Qualifications of process industry. Processes.5 (64): 1-18.

İnan İH (2006). Tekirdağ Ekonomisinin Gelişmesinde Tarım Sektörünün Yeri ve Önemi. Tekirdağ İlinin Ekonomik Gelişmesi. Seminer, Açılış-Tebliğler-Panel, s. 79-113, İktisadi Araştırmalar Vakfi, İstanbul.

İncekara A (2006). Tekirdağ İlinin Ekonomik Gelişmesinde Sanayi Sektörünün Yeri ve Önemi. Tekirdağ İlinin Ekonomik Gelişmesi. Seminer, Açıllş-Tebliğler-Panel, s.: 115-151, İktisadi Araştırmalar Vakfi, İstanbul.

İnci O (2014). Trakya Planlamasına İstanbul'un Desantralizasyonu Amaçlı Müdahalenin Boyutları ve Süreçleri. Trakya Çevre Sorunları (26 Kasım 2011) Seminer-Forum (Editörler: Prof. Dr. Osman İNCi, Av. Coşkun MOLLA, Çev. Müh.Ş. Boran İNCi), s.: 41-92, Türkiye Barolar Birliği Yayınlan: 240, Edirne.

Korkmaz H, Çetin B, Ege İ, Karataş A, Bom A, Özşahin E (2011). Environmental effects of stone pits in Hatay. Procedia Social and Behavioral Sciences. 19: 504-510.

Okay A, Okay N, Özgörüş Z (2008). Ganos Fay Zonu ve çevresinin Oligosen sonrası tektonik evrimi: Trakya'da paleotektonik dönemden neotektonik döneme geçişin niteliği. TÜBITTAK Proje No: $104 \mathrm{Y} 155$.

Özbey D (2005). Açık ocak madenciliği sonrası onarım çalışmalarında peyzaj mimarlarının rolü. İçinde: Madencilik ve Çevre Sempozyumu Bildiriler Kitabı, 5-6 Mayıs 2005, Ankara, Türkiye, s. 69-72.

Özcan AU (2009). Ankara-Hasanoğlan taş ocaklarının onarımı ve kentsel kullanım açısından değerlendirilmesi üzerine bir araştırma. Yayınlanmamıs Doktora Tezi, Ankara Üniversitesi Fen Bilimleri Enstitüsü Peyzaj Mimarlı̆̆ Anabilim Dalı, Ankara.

Özcan AU, Akpınar N (2009). Hasanoğlan taşocaklarında coğrafi bilgi sistemleri yardımıla çevresel risk alanlarının belirlenmesi. Ankara Üniversitesi Çevrebilimleri Dergisi. 2: 17-28.

Özşahin E (2015). Şarköy Deresi (Şarköy) - Bağlar Deresi (Marmara Ereğlisi) Arasındaki Marmara Denizi Akaçlama Havzasının (Tekirdağ) Jeomorfolojik Özellikleri. Akademik Sosyal Araştırmalar Dergisi. 10: 360-393. 
Özşahin E, Pektezel H, Eroğlu, İ (2016a). Geographical changes in Tekirdag and the surrounding region between 1900 and 2015. 4th International Geography Symposium Book of Abstracts 23 - 26 May 2016, Efe R and Curebal I (eds), Kemer, Antalya, Turkey, p. 229.

Özşahin E, Pektezel H, Eroğlu İ (2016b). Tekirdağ şehri ve yakın çevresinde arazi kullanımının zamansal ve mekânsal değişimi. Zeitschrift für die Welt der Türken / Journal of World of Turks. 8 (1): 307-326.

Özşahin E, Sarı H, Eroğlu, İ (2017a). Environmental effects of quarries in Naip plain and its surroundings (Tekirdag). International Symposium On GIS Applications in Geography \& Geosciences (ISGGG2017) Abstract Book, 18-21 October 2017, Özden, S, Akbulak RC, Erenoglu C, Karaca O, Saris F and Avcioglu M (eds), Canakkale, Turkey, p.12.

Özşahin E, Pektezel H, Eroğlu İ (2017b). Geographical changes in Tekirdag provinces and its neighbourhood during 1900-2015, pp.: 325-345, In: Chapter Nineteen Contemporary Studies in Environment and Tourism. Efe R and Öztürk M (eds), Cambridge Scholars Publishing, UK.

Polat C (2014). Toprağın Amaç Dışı Kullanımı ve Tarım Politikalarının Çevreye Etkisi. Trakya Çevre Sorunları (26 Kasım 2011) Seminer-Forum (Editörler: Prof. Dr. Osman İNCİ, Av. Coşkun MOLLA, Çev. Müh. Ş. Boran İNCI), s.: 33-40, Türkiye Barolar Birliği Yayınları: 240, Edirne.

Şahin S (2001). Türkiye'de tuğla-kiremit sanayiinin genel görünümü ve Çorum ili örneği. Gazi Üniversitesi Gazi Eğitim Fakültesi Dergisi. 21 (2): 19-41.

Şişman CB, Kocaman İ, Gezer E (2006). Tekirdağ yöresinde üretilen ve tarımsal yapılarda yaygın olarak kullanılan tuğlanın fiziksel ve mekanik özellikleri üzerine bir araştırma. Tekirdağ Ziraat Fakültesi Dergisi. 3 (1): 32-40.

Yıldız AK (2014). Çevrenin Kasten ve Taksirle Kirletilmesi Suçları (TCK m. 181, 182). Trakya Çevre Sorunları (26 Kasım 2011) Seminer-Forum (Editörler: Prof. Dr. Osman İNCİ, Av. Coşkun MOLLA, Çev. Müh. Ş. Boran İNCI), s.: 285-339, Türkiye Barolar Birliği Yayınları: 240, Edirne. 